\title{
Upaya Peningkatan Kompetensi Bahasa Inggris \\ Mahasiswa Jurusan Tarbiyah Program Studi Pendidikan Agama Islam \\ (PAI) STAIN Curup Dan Relevansinya Terhadap TOEFL Score Sebagai Syarat Wisuda
}

\author{
Leffi Noviyenty \\ Istitut Agama Islam Negeri (IAIN) Curup \\ gw_leffi@yahoo.com
}

\begin{abstract}
This is a descriptive qualitative research which investigates English Competence of PAI students in STAIN Curup, students' problems in facing TOEFL as one of graduation requiremnets in STAIN Curup. All PAI students who followed TOEFL is taken as sample of this research. Document analysis and deep interview are the techniques of collecting data. The informan are selected from Unit Pengembangan Bahasa (UPB)'s tutors and staff who responsible to held TOEFL. Data analysis is developed by comparing the three basic components, data reduction, data presentation and data conclusion/verification. The findings show that 1. PAI students' English competence on TOEFL needs to be improved since their average score is 351 and only 4 students got above 400 score; 2 . The problems they face on TOEFL are the material of TOEFL is not yet familiar to them, the students' attitude toward TOEFL is still low, English subjects during college are not enough to develop their English ability, even the lesson in English subjects is not relevan with TOEFL material, and there is no solution from the institution to help the students preparing TOEFL, so they can only solve the problem themselves; 3. Most of English lecturers are agree to develop a particular learning model for PAI students in preparing TOEFL.
\end{abstract}

\section{Keywords: TOEFL, Learning model, Islam Education}

\begin{abstract}
Abstrak: Penelitian ini adalah penelitian deskriptif kualitatif yang bertujuan untuk mendeskripsikan kompetensi bahasa Inggrismahasiswa Jurusan Tarbiyah Program Studi Pendidikan Agama Islam (PAI) STAIN Curup, mengetahui problem para mahasiswa Prodi. PAI dalam menghadapi TOEFL scoresebagai syarat wisuda dan menemukan rancangan model pembelajaran bahasa Inggris yang tepat untuk dapat membantu peningkatan kompetensi bahasa Inggris yang relevan dengan TOEFL score sebagai syarat wisuda. Sampel penelitian ini adalah seluruh mahasiswa Prodi. PAI yang mengikuti TOEFL di Unit Pengembangan
\end{abstract}


Bahasa (UPB) STAIN Curup tahun 2015. Data penelitian diperoleh dengan analisis dokumen (nilai TOEFL mahasiswa PAI) dan wawancara mendalam. Adapun informan diambil dari para dosen yang mengajar Bahasa Inggris di Prodi. PAI serta pengelola Unit Pengembangan Bahasa (UPB) STAIN curup yang bertanggungjawab terhadap pelaksanaan TOEFL. Tringgulasi digunakan untuk meningkatkan validitas penelitian. Analisis data dalam penelitian ini dibuat, dikembangkan, dan dikomparasikan dalam tiga komponen pokok, yaitu reduksi data, sajian data, dan penarikan simpulan/ verifikasi. Hasil penelitian menemukan bahwa, Kondisi kompetensi Bahasa Inggris mahasiswa Prodi. PAI STAIN Curup rata-rata masih rendah, minim, belum baik, belum dapat mencapai maksimal; Problem besar, berat, dan sangat mengganggu kelancaran mahasiswa calon wisudawan dalam menghadapi syarat wisuda ini disebabkan oleh beberapa faktor: 1. Materi TOEFL model tests, belum banyak diberikan; 2. materi kuliah bahasa Inggris dengan materi TOEFL tests kurang relevan; 3. Masih lemahnya sikap mahasiswa Prodi. PAI dalam menghadapi tuntutan TOEFL Score, sebagai salah satu syarat wisuda; 3 . Perkuliahan bahasa Inggris yang diaplikasikan pada waktu semester gasal dan semester genap pada tingkat satu, dirasakan sangat tidak cukup untuk membahas/menguasai materi TOEFL model tests; 4. Tampak tidak/belum ada penanganan problem mahasiswa ini secara efektif dari pihak berwenang terkait; 5. Problem TOEFL Score sebagai syarat wisuda selama ini ditemukan hanya dapat diatasi oleh mahasiswa yang bersangkutan (secara mandiri); dan Perlu dirancang model pembelajaran Bahasa Inggris yang paling tepat bagi mahasiswa Prodi. PAI STAIN Curup yang berpedoman, dan bertujuan pada TOEFL sebagai syarat wisuda.

\section{Kata Kunci : TOEFL, Model Pembelajaran, PAI}

\section{Pendahuluan}

Peningkatkan kompetensi mahasiswa khususnya dalam bahasa Inggris, dan tututan TOEFL Score sebagai salah satu syarat wisuda perlu mendapatkan perhatian serius dari dosen bahasa Inggris dan pihak terkait. Sasaran penjaminan mutu Sekolah Tinggi Agama Islam Negeri (STAIN) Curup jelas bahwa lulusan "mampu berkomunikasi global dengan TOEC Score minimal 350 minimal 70\%". ${ }^{1}$ Test Of English Competence (TOEC) yang umumnya lebih dikenal dengan TOEFL (Test Of English as a Foreing Language) harus diikuti oleh setiap mahasiswa yang akan menempuh ujian akhir studinya. Untuk memenuhi kebutuhan tersebut, perlu ditunjang strategi-strategi sukses yang diimplementasi dalam 
kegiatan pembelajarannya TOEFL,yaitu listening, reading, dan structure secara efektif.

Integritas-interkoneksi studi pada STAIN Curup ini membuat pendalaman materi bahasa Inggris umum bagi mahasiswa perlu diselaraskan dengan pemahaman tentang Islamic studies yang memadai. Problem besar mahasiswa Strata 1 dalam menghadapi tuntutan TOEFL/ TOEC Score sebelum mereka wisuda. Pada penelitian ini, peneliti menyoroti realita problem bagi mahasiswa Strata 1 (S1), Program Studi Pendidikan Agama Islam (PAI). Sehubungan dengan hal ini, juga menyoroti sikap dan upaya yang telah dilakukan dosen bahasa Inggris, serta pihak terkait. Secara faktual tampak problem serius sebagian besar mahasiswa STAIN Curup terhadap TOEFL score yang telah ditentukansebagai syarat wisuda.

Permasalahan para mahasiswa untuk mencapai strandar minimal yang telah ditentukan dalam kebijakan Penjamin Mutu STAIN Curup masih tampak menjadi kendala yang berat dan sangat mengganggu kelancaran menuju wisuda sebagian besar civitas akademika. Akar permasalahan TOEFL Score cukup kompleks, dan cukup fondamental. Belum berubahnya pemahaman akan kompetensi Bahasa Inggris bagi lulusan, tetapi kebijakan untuk sasaran mutu yang mensyaratkan adanya tanda lulus TOEFL test dengan standar minimal lulus TOEFL harus dijalankan. Hal ini bahkan memang terkesan seperti sesuatu yang dipaksakan.Secara faktual dapat dilihat dari volume waktu, intensitas materi, relevansi materi mata kuliah yang diaplikasikan kepada mahasiswa, dan belum termanfaatkannya secara maksimal layanan TOEFL preperation course yang relevan untuk TOEFL yang diberikan. Permasalahan mahasiswa tersandung TOEFL score akan berdampak harus tertunda-tundanya wisuda mereka. Kondisi memprihatinkan ini akan semakin krusial, dan perlu segera penanganan serius dari berbagai pihak yang terlibat. Ironisnya, problem yang akan relatif serius ini belum mendapat cukup perhatian dan antisipasi secara proporsional. Fenomena ini sungguh sangat menarik perhatian peneliti, dan hasil penelitian ini diharapkan bermanfaat bagi mahasiswa.

Upaya peningkatan kompetensi mahasiswa terhadap materi TOEFL diharapkan segera dapat dilakukan, guna membantu bagian permasalahan TOEFL Score bagi mahasiswa Prodi PAI.Penelitian ini dimaksudkan untuk menemukan solusi atas problem TOEFL Score secara efektif, dan akurat.Sehingga hasil penelitian ini dapat bermanfaat untuk mengantisipasi angka antrian jumlah mahasiswa yang tersandung TOEFL Score sebagai syarat 
wisuda.Karena mahasiswa, adalah generasi penerus bangsa, dan mutu pendidikan, harus diprioritaskan. Hal ini senada dengan PP RI Nomor 60 Tahun 1999 tentang Pendidikan Tinggi, yaitu: "Perguruan tinggi diharapkan menjadi pusat penyelenggaraan dan pengembangan pendidikan tinggi serta pemeliharaan, pembinaan dan pengembangan ilmu pengetahuan, telnologi dan / atau kesenian sebagai suatu masyarakat berpendidikan yang gemar belajar dan mengabdi kepada masyarakat serta melaksanakan penelitian yang menghasilkan manfaat yang meningkatkan mutu kehidupan bermasyarakat, berbangsa dan bernegara" ${ }^{2}$

Sehubungan dengan Pembukaan UUD 1945 alinea keempat ialah "mencerdaskan kehidupan bangsa"; Undang-Undang No 20 tahun 2003 tentang "Sistem Pendidikan Nasional"; Peraturan Pemerintah No 19 tahun 2005 tentang "Standar Pendidikan Nasional"; dan Undang-Undang No 14 tahun 2005 tentang "guru dan dosen menuntut adanya kualitas pendidikan". Betapapun, penguasaan kompetensi pedagogik, kompetensi profesional, kompetensi kepribadian, dan kompetensi sosial guru dan dosen mengacu pada amanat Undang-Undang dan Peraturan Pemerintah tersebut.Semua hal tersebut saling berkaitan dan tidak dapat dipisahkan, peningkatan kualitas pendidikan nasional yang harus diperhatikan elemen masyarakat, terutama civitas akademika.

Seperti halnya dengan seluruh program studi yang ada di lingkungan STAIN Curup, mata kuliah Bahasa Inggris 1 dan 2 merupakan mata kuliah wajib STAIN. Telah cukup lama masing-masing prodi hanya mempercayakan sepenuhnya tentang segala sesuatu yang berhubungan dengan mata kuliah tersebut kepada dosen yang bersangkutan. Beberapa fenomena lalu bermunculan, seperti belum terukurnya standar kompetensi mahasiswa jurusan non-PBI untuk mata kuliah Bahasa Inggris, silabus yang tidak seragam, sistem pemberian nilai yang tidak berimbang serta belum terukurnya kemampuan yang dicapai mahasiswa. Belum lagi teknik mengajar dosen Bahasa Inggris yang belum pada satu visi dan misi mata kuliah itu sendiri. Maka hasil penelitian ini nantinya diharapkan akan memberi kontribusi positif terhadap penyusunan materi kuliah Bahasa Inggris 1 dan 2 yang terarah pada kewajiban mahasiswa STAIN memenuhi standar score minimal TOEFL serta yang terpenting adalah medesain ulang paradigma berfikir mahasiswa STAIN Curup tentang TOEFL dan Bahasa Inggris sekalipun mereka tidak pada program studi Bahasa Inggris. 
Program studi Pendidikan Agama Islam (PAI) adalah program studi pertama dengan jumlah input mahasiswa terbanyak di STAIN Curup. Motivasi mahasiswa dalam belajar bahasa Inggris cukup tinggi, jika dilihat dari rata-rata nilai Bahasa Inggris mereka dibanding Prodi lain, terlebih lagi Kontribusi ketua prodi PAI cukup tinggi dalam menyeleksi tenaga pengajar Bahasa Inggris jika dibanding ketua prodi yang lain. Tetapi justru lemah pada hasil TOEFL test, bahkan dari hasil wawancara pada observasi awal, sebagian besar mahasiswa merasa belum mampu untuk mengikuti TOEFL tes, sementara TOEFL sudah menjadi lah satu syarat mahasiswa STAIN untuk wisuda.

Berdasarkan beberapa fenomena dan fakta diatas, peneliti tertarik menggali lebih jauh tentang TOEFL ini khususnya dari aspek upaya peningkatan kompetensi Bahasa Inggris mahasiswa jurusan tarbiyah program studi pendidikan Agama Islam STAIN Curup dan relevansinya terhadap TOEFL score sebagai syarat wisuda.

\section{Pembahasan}

Bahasa Inggris yang dipelajari mahasiswa, merupakan bahasa International pertama di dunia yang dipakai sebagai bahasa komunikasi baik lisan maupun tertulis/ Bahkan, di dunia pendidikan formal, bahasa Inggris diajarkan sejak sekolah dasar hingga perguruan tinggi, seperti yang diajarkan pada perkuliahan di Jurusan Tarbiyah Prodi. PAI ini. Di era globalisasi ini, kedudukan Bahasa Inggris semakin menguat karena bahasa Inggris dipakai hampir di semua bidang seperti: ilmu pengetahuan dan teknologi, komunikasi, politik, ekonomi, perdagangan, perbankan, budaya, seni, film, dan pendidikan. Sejalan dengan kebutuhan penguasaan bahasa Inggris, realisasi perkuliahan bahasa Inggris pada Prodi. PAI STAIN Curup, dan tuntutan TOEFL Score sebagai salah satu syarat wisuda sungguh memiliki persoalan yang perlu segera dipecahkan. Perkuliahan bahasa Inggris diberikan pada semerter pertama dan semerter kedua, tingkat pertama bagi mahasiswa Strata 1. Selanjutnya, ketentuan bahwa salah satu syarat bagi setiap mahasiswa yang akan menempuh wisuda adalah telah lulus ujian TOEFL dengan score tertentu, minimal $350^{3}$. Persoalan bagi mahasiswa non-jurusan bahasa Inggris pada Prodi. PAI STAIN Curup untuk memenuhi syarat minimal TOEFL Score tersebut cukup besar, dan perlu mendapat perhatian khusus, serta penanganan yang efektif.

\footnotetext{
${ }^{3}$ Penjamin Mutu Internal STAIN Curup
} 
Materi perkuliahan bahasa Inggris sangatlah penting dalam menentukan proses perkuliahan yang efektif. Dosen yang profesional selalu berfikir bagaimana mengembangkan strategi pembelajaran di kelas, dalam mengembangkan strategi pembelajaran juga disesuaikan dengan karakteristik dan lingkungan belajar mahasiswa.Misalnya, kebutuhan mahasiswa adalah meningkatkan kompetensi TOEFL Score, maka pembahasannya harus difokuskan pada kajian materi TOEFL, danstrategi pembelajarannya untuk mencapai goal.Sehubungan dengan interkoneksi pada lembaga STAIN Curup, maka perlu diimplementasikannya materi Islamic studies, pada bagian reading comprehension.Koordinasi dan kerjasama yang baik dan kondusif antar civitas akademika serta sikap kooperatif untuk kepentingan peningkatan kompetensi bahasa Inggris mahasiswa sangatlah dibutuhkan.

Pemberian materi harus diorientasikan pada tingkat kebutuhan penguasaan materi yang diperlukan mahasiswa sesuai dengan tingkat kompetensi yang harus dicapai, dan bersifat edukatif. Mengajar dan mendidik tidak dapat terpisahkan di dalam kegiatan belajar mengajar.Mengajar, yaitu memberikan materi perkuliahan kepada mahasiswa yang relevan guna meningkatkan terutama pada ranah kompetensi kognitif mahasiswa.Sedangkan, mendidik, yaitu mengembangkan kemampuan, membentuk watak, membangun peradaban yang bermartabat, mencerdaskan kehidupan bangsa.

\section{A. Deskripsi KompetensiBahasa Inggris Mahasiswa Program Studi PAI STAIN Curup pada TOEFL Score.}

Tabel 1

TOEFL Score Calon Wisudawan STAIN Curup

Program Studi PAI 2015

\begin{tabular}{|l|l|l|l|l|l|}
\hline \hline \multirow{2}{*}{ No } & Mahasiswa & \multicolumn{2}{|l|}{ Nilai rata-rata kemampuan: } & $\begin{array}{l}\text { Score } \\
\text { rata-rata }\end{array}$ \\
\cline { 3 - 5 } & & $\begin{array}{l}\text { Listening } \\
\text { Comprehension }\end{array}$ & $\begin{array}{l}\text { Written } \\
\text { Expression }\end{array}$ & $\begin{array}{l}\text { Reading } \\
\text { Comprehension }\end{array}$ & \\
\hline \hline 1 & 53 & $\begin{array}{lll}1972: 53 \\
=37\end{array}$ & $\begin{array}{l}1846: 53 \\
=35\end{array}$ & $\begin{array}{l}1781: 53 \\
=33\end{array}$ & $\begin{array}{l}18617: 53 \\
=351\end{array}$ \\
\hline & & & & 351 \\
\hline \hline
\end{tabular}




\begin{tabular}{|l|l|}
\hline $300-350$ & 25 orang \\
$351-400$ & 24 orang \\
$401-450$ & 0 orang \\
$451-500$ & \\
\hline Score TOEFL Terendah & 310 \\
\hline Score TOEFL tertinggi & 410 \\
\hline
\end{tabular}

Data tabel I di atas, menunjukkan bahwa dari 53 orang calon wisudawan Program Studi PAI yang mengikuti TOEFL sebagai salah satu syarat wisuda hanya 4 orang yang memperoleh nilai skore TOEFL diatas 400. Sebagian besar calon wisudawan memperoleh skor 300 - 350. Bila diklasifikasikan berdasarkan kemempuan per aspek materi uji TOEFL, 53 calon wisudawan memiliki skor hampir berimbang untuk 3 aspek, listening comprehension, written exprression dan reading comprehension yakni 33 - 37. Skor yang diperoleh telah dikonversi sesuai dengan teknik penghitungan skor TOEFL dengan rumus

nilai jawaban benar untuk 3 aspek setelah dikonversi ke TOEFL

(listening comprehension + written expression + reading comprehension), dijumlahkan lalu hasilnya di bagi 3 .

Sarana dan prasarana peserta TOEFL bagi mahasiswa Prodi.PAI cukup baik namun terus harus ditingkatkan.Unit Pengembangan Bahasa STAIN Curup telah memfasilitasi mahasiswa PAI dengan 1 labor multimedia dan satu labor manual yang keduanya dapat digunakan untuk uji kompetensi Listening, atau keerampilan mendengar pada TOEFL.UPB juga memiliki 6 paket soal TOEFL lengkap beserta kunci jawaban dan lembar jawaban.Paket soal ini digunakan bergantian pada setiap gelombang tes.Disamping sarana, UPB juga telah membuka program bimbingan belajar 2 level, yakni Introduction to TOEFL dan TOEFL Preparation.Program ini diperuntukkan bagi seluruh mahasiswa STAIN curup. Sebelum memasuki program bimbingan TOEFL ini, ada beberapa program awal yang juga bisa diikuti mahasiswa yakni General English 1 dan 2.Program bimbingan ini memberikan pengetahuan awal tentang seluruh aspek keterampilan Bahasa Inggris Reading, Speaking, Listening dan Writing yang diarahkan pada pengetahuan dasar menuju TOEFL.Fakta memperlihatkan bahwa program-program yang telah dibuka oleh UPB sejak sebelum pemberlakuan TOEFL sebagai syarat Wisuda ini belum diikuti oleh mahasiswa 
PAI.Hasil angket yang disebarkan ke mahasiswa menyebutkan kurangnya sosialisasi program sebagai program yang diperuntukkan bagi seluruh mahasiswa STAIN adalah sebab utamanya.Disamping itu, buku-buku sebagai referensi TOEFL masih sangat kurang di UPB.

Mengingat pentingnya program-program yang mengarah ke TOEFL, sebaiknya UPB semakin memperluas pemahaman akan tujuan dan manfaat program-program tersebut di kalangan mahasiswa.Relevansi mata kuliah Bahasa Inggris dengan materi TOEFL bagi mahasiswa Prodi. PAI masih dirasa kurang. Materi kuliah Bahasa Inggris memang belum sama sekali dikaitkan dengan materi TOEFL. Para dosen diberikan kebebasan untuk merancang materi kuliah sesuai dengan silabus yang telah disiapkan oleh Prodi. PBI. Sementara penyusunan silabus mata kuliah Bahasa Inggrispun dibuat oleh dosen yang bersangkutan tanpa merujuk pada materi TOEFL. Terlebih latihan keterampilan mendengar atau Listening, yang menjadi salah satu keterampilan berbahasa pada mata kuliah Bahasa Inggris tidak pernah diberikan di labor bahasa.

Mempertimbangkan tujuan pengajaran Bahasa Inggris di Prodi. PAI belum dapat dirumuskan secara spesifik oleh Prodi. PAI dan STAIN Curup, maka TOEFL dapat dipertimbangkan sebagai tujuan akhir mengukur kompetensi bahasa Inggris yang harus dimiliki mahasiswa PAI. Oleh karena itu, relevansi materi kuliah Bahasa Inggris dengan materi TOEFL perlu dibangun dan selalu ditingkatkan.Kompetensi Bahasa Inggris mahasiswa PAI terhadap materi TOEFL.Kompetensi Bahasa Inggris mahasiswa Prodi. PAI ditemukan belum baik, baru mencapai cukup saja. Pada dasarnya mahasiswa Prodi. PAI memiliki potensi yang cukup baik dan bisa menjadi baik jika ditunjang sarana dan prasarana pendukungnya. Kompetensi mahasiswa dapat ditingkatkan menjadi sangat baik jika ditingkatkan pula daya dukungnya secara maksimal dan efektif.

Sikap mahasiswa Prodi. PAI dalam menghadapi skor TOEFL sebagai salah satu syarat wisuda dengan jawaban cukup baik sebanyak 45,2 \%, kurang baik sebanyak 30,2\%. Artinya, sikap mahasiswa masih (kurang) cukup baik merespon perlunya TOEFL Score, perlu dimotivasi dan diberikan pemahaman arti pentingnya penguasaan Bahasa Inggris bagi mahasiswa, dan alumni.Sebab, mereka terkendala oleh berbagai keterbatasan.Sangat perlu ditingkatkan sosialisasi pemahaman arti pentingnya kompetensi Bahasa Inggris bagi mahasiswa, dan lulusan. Bahwa kompetensi bahasa Inggris, dan TOEFL Score 
bukan hanya untuk syarat wisuda tetapi lebih dari itu.Ketika mahasiswa atau lulusan akan mencari pekerjaanataupun melanjutkan studi ke jenjang yang lebih tinggi, akan sangat diperlukanskor TOEFL tertentu sebagai syarat yang harus dipenuhihanya pada tahap seleksi berkas pendaftaran saja. Bahkan tak jarang setelah yang bersangkutan lulus berkas, akan dilakukan TOEFL lagi di beberapa universitas terkemuka.Pelayanan/pelaksanaan TOEFL di Unit Pengembangan Bahasa STAIN Curup bagi mahasiswa PAI ditemukan 28,3 \% sangat baik, 54,7 $\%$ biasa saja dan 16,98 \% tidak baik. Artinya, sudah jelas bahwa pelayanan/pelaksanaan TOEFLtests bagi mahasiswa PAI di Unit Pengembangan Bahasa (UPB) benar-benar baik. Proses administrasi, pengelompokan peserta tes, distribusi soal dan pengawasan tes dirasa baik. Hal ini senada dengan informasi yang diperoleh dari Unit Pengembangan Bahasa (UPB) dan buktibukti pendukung yang diperlihatkan untuk memperkuat informasi tersebut. Mahasiswa diizinkan mendaftar TOEFL dengan syarat mengumpulkan jadual ujian munaqosah yang ditandatangani ketua jurusan ataupun berita acara ujian munaqosah yang telah ditandatangani tim penguji. Setiap sesi tes hanya diperuntukkan bagi 50 calon wisudawan.

Soal TOEFL dibuat dalam bentuk buku yang dijilid dengan rapi, bersih dan jelas, begitu juga lembar jawaban tes. Satu kelas diawasi oleh 1 orang pengawas. Penghitungan skor juga dilakukan segera setelah satu gelombang tes berakhir dan langsung dibuat sertifikat yang memuat nilai skor TOEFL dan foto peserta tes. Hal ini dimaksudkan untuk menghindari pemalsuan nilai skore TOEFL. Sikap pengelola TOEFL terhadap tuntutan TOEFL score bagi mahasiswa diresponnya dengan sangat baik sebanyak 32\%, baik,66 \%,dan kurang baik 1,8\%. Artinya, pengelola Unit Pengembangan Bahasa (UPB) STAIN Curup telah berupaya dengan baik merespon dan memberikan pelayanan baik untuk kepentingan mahasiswa dalam memenuhi kebutuhan TOEFL Scoresebagai syarat wisuda. Bahkan, telah diupayakan legalitas dari pihak kampus untuk meng-SK- kan keputusan TOEFL sebagai salah satu syarat wisuda di STAIN Curup.

Cara pengelola UPB dalam mengatasi problem tuntutan TOEFL bagi mahasiswa Prodi. PAI secara umum cukup baik 35,8\% dan 26,4 \% kurang baik). Hal ini senada dengan hasil inteview kepada pihak pengelola TOEFL yakni UPB sendiri, bahwa UPB telah melakukan beberapa langkah yakni, sosialisasi TOEFL sebagai syarat wisuda, pelaksanaan TOEFL yang belum menetapkan skor minimal, simulasi TOEFL di kelas Bahasa Inggris 1 dan Bahasa Inggris 2, serta 
penguatan materi TOEFL melalui program bimbingan yakni Introduction to TOEFL dan TOEFL Preparation bagi mahasiswa.

Dinyatakan koordinasi kerjasama antara pihak STAIN, UPB, Jurusan, Prodi dan mahasiswa 15\% sangat baik; 50,9 \% baik; $28 \%$ cukup baik dan 5,6 \% kurang baik. Artinya, koordinasi dari pihak-pihak terkait memang terbukti baik, namun perlu ditingkatkan ke taraf yang lebih baik lagi. UPB telah melakukan 3 kali pertemuan dalam rangka pelaksanaan TOEFL sebagai syarat wisuda, yakni sosialisasi awal dengan para ketua Himpunan Mahasiswa Jurusan (HMPJ), ketua Himpunan Mahasiswa Program Studi (HMPS), Ketua Prodi, Ketua Jurusan dan Wakil Ketua 1 bidang Akademik, Wakil Ketua 2 dan wakil ketua 3. Koordinasi kedua dengan seluruh Ketua Program Studi dan Ketua Jurusan serta pertemuan ketiga dilakukan dengan Ketua STAIN serta wakil Ketua 1 Bidang akademik. Dari ketiga koordinasi tersebut telah diputuskan untuk membuat legalitas resmi pemberlakuan TOEFL sebagai syarat wisuda dalam bentuk Surat Keputusan ketua STAIN Curup, serta menyepakati skor minimal sebagai syarat kelulusan TOEFL tersebut untuk wisudawan tahun 2016 mendatang. Kedua temuan dari dua sumber yang berbeda ini menguatkan bukti bahwa memang telah terjalin koordinasi yang terstruktur dan terencana antara pihak STAIN, UPB, jurusan, Prodi dan mahasiswa.

\section{B. Mengapa para mahasiswa Prodi PAI menghadapiproblem TOEFL scores sebagai syarat wisuda.}

1. Problem serius mahasiswa terhadap tuntutan TOEFL Score, syarat wisuda ternyata lebih besar $(52,8 \%$ ), dan yang menganggapnya sebagai problem biasa lebih sedikit $(18,8 \%)$ dan yang tidak menganggapnya masalah sebesar 28,3\%. Artinya, bahwa persoalan mahasiswa terhadap target minimal TOEFL Score, syarat wisuda dirasa sebagai persoalan serius yang perlu segera dipecahkan secara akurat oleh pihak-pihak terkait agar tidak berlarut-larut. Bahkan, TOEFL Score, bukan hanya dapat digunakan sebagai pemenuhan salahsatu syarat wisuda, tetapi dapat digunakan untuk kelanjutan syarat mendapatkan pekerjaan, ataupun syarat studi ke jenjang yang lebih tinggi, serta menjadikannya sebagai salahsatu alat kompetisi meraih prestasi.

2. Problem terhadap TOEFL Score sebagai syarat wisuda dirasakan sangat berat $(75,5 \%)$, dan yang menganggapnya sebagai beban yang hanya biasa saja, yaitu lebih sedikit (24,5\%). Artinya, kondisi ini perlu segera diupayakan jalan keluarnya, jalan pemecahannya supaya tidak 


\section{3}

Leffi Noviyenty : Upaya Peningkatan Kompetensi Bahasa Inggris..|

memberatkan sekali. Sebenarnya, jika alternatif solusinya disediakan untuk mahasiswa yang merasakan sangat berat dengan TOEFL Score sebagai syarat wisuda itu, sekaligus akan menjadi solusi bagi mahasiswa yang merasakan berat biasa saja, yaitu sarana Introduction to TOEFL dan TOEFL Preparation Course, dan valume intensitas jam mata kuliahnya ditingkatkan.

3. Problem TOEFL Score dianggap biasa saja artinya tidak mempengaruhi kelancaran pendaftaran wisuda dirasakan dan dinyatakan oleh besarnya temuan, yaitu sebesar 41,55 \%. Sedangkan bagi yang menganggapnya tidak begitu mengganggu kelancaran pendaftaran hanya relative sedikit, yaitu $37,7 \%$. Artinya, persoalaan TOEFL Score sebagai syarat wisuda bagi mahasiswa Prodi. PAI relatif tidak mengganggu kelancaran pendaftaran wisuda. Tetapi masih ditemukan 20,75\% mahasiswa menganggap TOEFL sebagai syarat wisuda sangat mengganggu bahkan mempersulit mahasiswa untuk mendaftar wisuda. Hal ini sangat penting mendapat prioritas jalan pemecahannya, sehingga TOEFL Score sebagai syarat wisuda ini tidak lagi sangat mengganggu kelancaran pendaftaran wisuda, tetapi justru menjadi kebanggaan masing-masing atas keilmuan bahasa Inggris yang dapat menjadi pembuka pintu masuk menuju ranah keilmuan, dan pekerjaan yang lebih luas.

4. Problem TOEFL Score bagi mahasiswa telah diatasi oleh pihak terkait di lembaga ini, ditemukan tidak/belum ada penanganan secara efektif dari pihak berwenang terkait ternyata lebih besar (77,3\%), dan adanya penanganan dari pihak berwenang terkait, ditemukan jawabannya lebih kecil (22,6 \%). Artinya, problem TOEFL Score bagi mahasiswa ditemukan tidak/belum ada penanganan secara efektif dari pihak berwenang terkait, atau penanganan terhadap problem TOEFL Score bagi mahasiswa ditemukan lebih rendah, belum maksimal diatasi oleh pihak terkait di lembaga ini. Tidak menutup kemungkinan, jika problem TOEFL Score bagi mahasiswa ini tidak segera diatasi oleh pihak terkait di lembaga ini, membuat problem semakin besar, mengingat tuntutan kompetensi bahasa Inggris di era globalisasi ini semakin meningkat.

5. Problem TOEFL Score sebagai syarat wisuda selama ini ditemukan hanya dapat diatasi oleh mahasiswa yang bersangkutan (secara mandiri) dinyatakan sebesar 56,6\%, dan hanya 33,9\% diatasi, terbantukan oleh sarana dan fasilitas di lembaga ini. Artinya, peran pengelola dan dosen 
bahasa Inggris seharusnya ditingkatkan atau bahkan dimaksimalkan, agar persoalan dapat diatasi secara efektif, dan maksimal.

6. Problem mahasiswa terhadap TOEFL terutama terhadap penguasaan materi dari TOEFL sebesar66 \%, dan tehnis di luar materi hanya sebesar 9,4\%. Artinya, problem para mahasiswa terhadap penguasaan materi TOEFL dinyatakan relatif besar, sedangkan yang sifatnya hanya tehnis, di luar materi hanya relatif kecil, yaitu hanya $6,50 \%$ nya materi TOEFL.

7. Materi TOEFLmodel tests yang sungguh banyak dan penting untuk didiskusikan dan latihkan. Namun hal ini ditemukan bahwa materi TOEFLmodel tests relatif besar tidak dilatihkan/diberikan sebesar 94,3\%. Artinya, kondisi ini sebenarnya yang menjadikan salah satu pemicu problem bagi mahasiswa terhadap rendahnya penguasaan materi yang relevan sebelum dihadapkan pada TOEFL tests dan TOEFL Score sebagai syarat wisuda.

8. Perkuliahan Bahasa Inggris yang diaplikasikan pada waktu semester gasal dan atau semester genap pada tingkat satu, dirasakan sangat tidak cukup untuk membahas/menguasai materi TOEFL model tests. Hal ini ditemukan bahwa tidak cukupnya materi TOEFL model tests diberikan untuk menguasai TOEFL tests di waktu perkuliahannya yang juga relatif singkat, sebesar 77, $4 \%$. Artinya, kondisi ini menunjukkan bahwa tingkat perbandingan antara perkuliahan untuk dapat membantu penguasaan materi TOEFL dengan kondisi yang harus dipersiapkan untuk menguasai materi TOEFL relatif jauh.

9. Program Introduction to TOEFL dan TOEFL Preparation Course dirasakan manfaatnya dapat membantu mahasiswa Prodi. PAI dalam memecahkan problem tuntutan TOEFL Score sebagai syarat wisuda. Ternyata program yang masih sangat baru dan belum diimplementasikan secara maksimal saja, ditemukan ada manfaatnya $(18,8 \%$.)dan yang menyatakan belum dapat menikmati program tersebut di STAIN curup yang dapat membantu permasalahan ditemukan relatif besar $(81 \%)$. Program Introduction to TOEFL dan TOEFL Preparation Coursebaru diadakan sekitar awal Februari 2015, dan mahassiwa masih harus membayar. Meskipun pesertanya relatif sedikit di Unit Pengembangan Bahasa (UPB), ternyata sudah dapat dirasakan manfaatnya bagi mahasiswa untuk lebih mempersiapkan latihan sebelum mengikuti TOEFL tests, dan untuk meningkatkan TOEFL Score nya. Artinya, program Introduction to 


\section{5}

Leffi Noviyenty : Upaya Peningkatan Kompetensi Bahasa Inggris.. |

TOEFL dan TOEFL Preparation Course sangat penting untuk diimplementasikan di STAIN Curup, karena program ini dapat menjadi salahsatu solusi mengatasi problem penguasaam materi TOEFL model tests secara efektif dan akurat.

10. Penanganan problem tuntutan problem TOEFL Score sebagai syarat wisuda dirasakan bagi mahasiswa Prodi. PAI ini, relatif sedikit (13,2\%), dan yang menyatakan belum ada penanganan atas persoalan TOEFL Score ternyata justru relatif besar (86,79 \%). Artinya, penanganan problem TOEFL Score sebagagi syarat wisuda di STAIN Curup ini merupakan tantanganbesar yang perlu penanganan secara efektif dan akurat.

Problem besar, berat, dan sangat mengganggu kelancaran mahasiswa mendaftar wisuda ini disebabkan oleh beberapa faktor:

1. Materi TOEFL model tests, belum banyak diberikan.

2. kurangnya relevansi materi kuliah Bahasa Inggris dengan materi TOEFL tests.

3. Masih lemahnya sikap mahasiswa Prodi. PAI dalam menghadapi tuntutan TOEFL Score sebagai salah satu syarat wisuda.

4. Kurang intensif dan volume belajar TOEFL model tests bagi mahasiswa. Perkuliahan Bahasa Inggris yang diaplikasikan pada waktu semester gasal dan atau semester genap pada tingkat satu, dirasakan sangat tidak cukup untuk membahas/menguasai materi TOEFL model tests

5. Tampak tidak/belum ada penanganan problem mahasiswa ini secara efektif dari pihak berwenang terkait.

6. Problem TOEFL Score sebagai syarat wisuda selama ini ditemukan hanya dapat diatasi oleh mahasiswa yang bersangkutan (secara mandiri).

7. Belum tersosialisasikan dengan baiknya program Introduction to TOEFL dan TOEFL Preparation Course yang diaplikasikan secara proporsional guna membantu mahasiswa PAI memecahkan problem tuntutan TOEFL Score sebagai syarat wisuda. Sementara ini, ada program Introduction to TOEFL dan TOEFL Preparation Course yang baru diadakan sekitar awal februari 2015, masih dipungut biaya dan belum dapat dimaksimalkan, meskipun bagi mahasiswa yang ikut, dapat menikmati manfaatnya, namun dalam jumlah yang relatif kecil. \

\section{Rancangan model pembelajaran bahasa Inggris yang tepat bagi mahasiswa Pogram Studi Pendidikan Agama Islam STAIN Curup.}


Bagian ini dapat menjawab rumusan permasalahan ketiga dalam penelitian ini, yaitu "Bagaimanakah rancangan model pembelajaran Bahasa Inggris yang tepat untuk dapat membantu peningkatan TOEFL score mahasiswa Prodi. PAI STAIN Curup?"

1. Perlu dirancang model pembelajaran Bahasa Inggris yang paling tepat bagi mahasiswa Prodi. PAI STAIN Curup. Hal ini disetujui oleh semua $(100 \%)$ dosen Bahasa Inggris STAIN Curup. Artinya, dengan meningkatnya kebutuhan kompetensi Bahasa Inggris mahasiswa Prodi. PAI, maka sungguh diperlukan rancangan model pembelajaran Bahasa Inggris yang paling tepat bagi mahasiswa Prodi. PAI STAIN Curup.

2. Seluruh $(100 \%)$ dosen Bahasa Inggris STAIN Curup setuju jika materi perkuliahan Bahasa Inggris difokuskan pada materi TOEFL untuk meningkatkan TOEFL Score. Hal ini juga akan membantu memperjelas tujuan pembelajaran Bahasa Inggris di program studi non Bahasa Inggris. Disamping itu seluruh dosen menyepakati bahwa jika materi perkuliahan telah mengarah pada TOEFL, silabus akan seragam dan pengembangan bahan ajarpun akan memiliki pedoman yang jelas dan terukur, begitu juga keberhasilan pengajaran mata kuliah Bahasa Inggris akan dapat lebih terukur.

3. Dari 10 dosen Bahasa Inggris , $8(80 \%)$ dosen setuju jika perkuliahan Bahasa Inggris di orientasikan pada TOEFL model test agar efektif. Artinya, pernyataan mayoritas dosen Bahasa Inggris STAIN Curup setuju jika perkuliahan Bahasa Inggris di orientasikan pada TOEFL model test secara efektif. Dalam 10 orang dosen tersebut, 5 orang dosen setuju jika orientasi kajian ke Islaman juga dimasukkan sebagai orientasi tambahan yang mungkin nantinya bisa divariasikan dalam TOEFL terutama pada reading comprehension.

4. Seluruh $(100 \%)$ dosen setuju jika persoalan tuntutan TOEFL Score lebih diperhatikan oleh pihak terkait. Artinya, bahwa kondisi persoalan TOEFL Score yangbelum mendapat cukup perhatian, supaya segera diprioritaskan untuk keberhasilan ribuan mahasiswa dan mutu pendidikan. Wujud perhatian pihak terkait untuk peningkatan kualitan pembelajaran bahasa Inggris di lingkungan Prodi. PAI khususnya dan di STAIN Curup pada umumnya perlu segera direalisasikan untuk kemaslahatan dan kesuksesan semua.

5. Seluruh (100\%) dosen sangat setuju jika dibangun kerjasama yang baik antar dosen Bahasa Inggris Prodi. PAI dengan pengelola Unit Pengembangan Bahasa (UPB).Kerjasama ini akan sangat membantu kesberhasilan 
pengelolaan TOEFL ke depan. Sosialisasi akan beberapa langkah bantuan bagi mahasiswa dalam usaha mereka memperbaiki skor TOEFL akan sangat efektif jika dimulai dari program studi dan jurusan. Kesepakatan akan skor TOEFL minimal sebagai passing grade, perlu dikuatkan dengan Surat Keputusan pimpinan STAIN Curup sehingga bisa disepakati pemberlakuannya secara hukum oleh seluruh program studi di STAIN Curup. Program studi pun akan dapat memonitor dan mengevaluasi efektivitas pembelajaran mata kuliah Bahasa Inggris berdasarkan keseragaman silabus yang dipusatkan di Unit Pengembangan Bahasa (UPB). Artinya, kerjasama seluruh sivitas akademik STAIN Curup akan menentukan keberhasilan pelaksanaan dan manfaat TOEFL di STAIN Curup.

6. Seluruh (100\%) dosen sangat setuju jika segera direalisasikan model pembelajaran Bahasa Inggris berdasarkanpada TOEFL model test. Hal ini dikarenakan TOEFL sudah diberlakukan sebagai salah satu syarat wisuda sejak wisuda gelombang pertama tahun 2015 .

7. Sejumlah 7 dari 10 orang $(70 \%)$ dosen Bahasa Inggris sangat setuju jika volume Bahasa Inggris sedikit ditambah guna memperkuat kemampuan Bahasa Inggris mahasiswa Program studi PAI mengingat kompetensi dan kebutuhan mahasiswa terhadap pentingnya Bahasa Inggris untuk kemajuannya di jaman globalisasi ini, serta relevansinya dengan tuntutan TOEFL Score sebagai syarat wisuda yang tampak menjadi problem besar sampai saat ini.

8. Seluruh(100\%) dosen Bahasa Inggris sangat setuju jika ada team perancang model pembelajaran Bahasa Inggris mengingat tuntutanTOEFL Score bagi mahasiswa. Artinya, semua dosen bahasa Inggris sangat setuju jika ada team perancang model pembelajaran bahasa Inggris mengingat tuntutan TOEFL Score bagi mahasiswa, karena untuk menjaga kualitas produk program besar ini, maka kebersamaan tanggungjawab tim sangat penting artinya untuk sebuah kesuksesan.

9. Seluruh(100\%) dosen bahasa Inggris sangat setuju jika dibangun kerjasama team perancang model pembelajaran Bahasa Inggris dengan pihak terkait di lembaga inikarena program ini besar dan tentu saja melibatkan banyak pihak dan kerjasama team secara maksimal.

10. Sebagian besar dosen bahasa Inggris sangat setuju 70\% (7 orang)dan setuju (3 orang) jika hasil penelitian ini segera diupayakan untuk mengatasi problem tuntutan TOEFL score bagi mahasiswa. 
Temuan ketiga menjawab rumusan permasalahan ketiga dalam penelitian ini, yaitu "Bagaimanakah rancangan model pembelajaran bahasa Inggris yang tepat untuk dapat membantu peningkatan TOEFL score mahasiswa Program Studi Pendidikan Agama Islam (PAI) STAIN Curup?” Bahwa perlu dirancang model pembelajaran Bahasa Inggris yang paling tepat bagi mahasiswa Prodi. PAI STAIN Curup. Hal ini disetujui oleh semua dosen Bahasa Inggris STAIN Curup dan pengelola Unit Pengembangan Bahasa (UPB) STAIN Curup.Bahkan, sebagian besar dosen Bahasa Inggris setuju jika materi perkuliahan Bahasa Inggris difokuskan pada materi TOEFL untuk meningkatkan TOEFL Score mahasiswa. Para dosen setuju jika perkuliahan Bahasa Inggris di orientasikan pada TOEFL model test danreading diorientasikan pada Islamic Studies agar efektif. Para dosen Bahasa Inggris sangat setuju jika persoalan tuntutan TOEFL Score lebih diperhatikan serius dan dibangun komunikasi oleh pihak-pihak terkait, yaitu para dosen Bahasa Inggris, pengelola di UPB, dan beberapa pihak yang berwenang di STAIN Curup.

Selain itu, para dosen Bahasa Inggris sangat setuju jika volume bahasa Inggris sedikit ditambah guna memperkuat kemampuan Bahasa Inggris mahasiswa Prodi. PAI. Sangat diharapkan untuk mengatasi problem TOEFL di lembaga ini, jika ada team perancang model pembelajaran Bahasa Inggris mengingat tuntutanTOEFL Score, bukan hanya untuk salah satu syarat wisuda, tetapi bisa untuk banyak kepentingan, yaitu untuk mendapatkan beasiswa, studi lanjut ke luar negeri, studi ke jenjang yang lebih tinggi, maupun untuk pekerjaan. Bahkan, para dosen Bahasa Inggris sangat setuju jika hasil penelitian ini segera diupayakan untuk mengatasi problem tuntutan TOEFL score, sebagai syarat wisuda bagi mahasiswa STAIN curup khususnya Prodi. PAI.

\section{Kesimpulan}

Kondisi kompetensi Bahasa Inggris mahasiswa Prodi. PAI STAIN Curup yang juga didukung data TOEFL Score di Unit Pengembangan Bahsa (UPB) ditemukan rata-rata masih rendah, minim, belum baik, belum dapat mencapai maksimal, meskipun sarana / prasarana peserta, dan pengelola telah memberikan pelayanan/pelaksanaan TOEFLtests bagi mahasiswa Prodi. PAI di Unit Pengembangan Bhasa (UPB) STAIN Curup sudah cukup baik.

Problem besar, berat, dan sangat mengganggu kelancaran mahasiswa calon wisudawan dalam menghadapi syarat wisuda ini disebabkan oleh beberapa faktor: 1. Materi TOEFL model tests, belum banyak diberikannya; 2.kurang relevansi materi kuliah bahasa Inggris dengan materi TOEFL tests; 3. Masih 
lemahnya sikap mahasiswa Prodi. PAI dalam menghadapi tuntutan TOEFL Score , sebagai salah satu syarat wisuda; 3. Kurang intensif dan volume belajar TOEFL model tests bagi mahasiswa. Perkuliahan bahasa Inggris yang diaplikasikan pada waktu semester gasal dan atau semester genap pada tingkat satu, dirasakan sangat tidak cukup untuk membahas/menguasai materi TOEFL model tests; 4.Tampak tidak/belum ada penanganan problem mahasiswa ini secara efektif dari pihak berwenang terkait; 5. Problem TOEFL Score, yarat wisuda selama ini ditemukan hanya dapat diatasi oleh mahasiswa yang bersangkutan (secara mandiri).

Perlu dirancang model pembelajaran Bahasa Inggris yang paling tepat bagi mahasiswa Prodi. PAI STAIN Curup. Hal ini disetujui oleh semua dosen bahasa Inggris dan pengelola Unit Pengembangan Bahasa (UPB). Sebagian besar dosen bahasa Inggris setuju jika materi perkuliahan Bahasa Inggris difokuskan pada materi TOEFL untuk meningkatkan TOEFL Score mahasiswa. Para dosen setuju jika perkuliahan Bahasa Inggris di orientasikan pada TOEFL model test dan reading orientasikan pada Islamic Studies agar efektif. para dosen bahasa Inggris sangat setuju jika persoalan tuntutan TOEFL Score lebih diperhatikan serius dan dibangun komunikasi oleh pihak-pihak terkait. Pernyatan setuju para dosen agar hal ini segera mendapat perhatian pihak terkait, yaitu para dosen Bahasa Inggris, pengelola di Unit Pengembangan Bahasa (UPB), dan beberapa pihak yang berwenang di STAIN Curup.

Selain itu, para dosen Bahasa Inggris sangat setuju jika volume bahasa Inggris sedikit ditambah guna memperkuat kemampuan bahasa Inggris mahasiswa, (Misal: 2sks/sem/kelas). Sangat diharapkan untuk mengatasi problem TOEFL di lembaga ini, jika ada team perancang model pembelajaran Bahasa Inggris mengingat tuntutanTOEFL Score, bukan hanya untuk salah satu syarat wisuda, tetapi bisa untuk banyak kepentingan, yaitu untuk mendapatkan beasiswa, studi lanjut ke luar negeri, studi ke jenjang yang lebih tinggi, maupun untuk pekerjaan. Bahkan, para dosen Bahasa Inggris sangat setuju jika hasil penelitian ini segera diupayakan untuk mengatasi problem tuntutan TOEFL score sebagai syarat wisuda bagi mahasiswa STAIN Curup ke depannya. 


\section{Bibliografi}

Allen, Stannard. 1987. Living English Structure. London: Longman

Azar, Betty Scrampfer. 1989. Understanding and Using English Grammar. New Jersey: Prentice Hall.

Azar, betty Scrampfer. 2000. Fundamental English Grammar. New Jersey: Prentice Hall.

Azar, Betty Scrampfer. 2001. Basic English Grammar. New Jersey: Prentice Hall Regents.

Brown, G., Malmkjar, K., and Williams, J. 1996. Performance and Competence in Second Language Acquisition. Cambridge: Cambridge University.

Brown, H. Douglas. Teaching by Principles. 1994. Prentice Hall Inc. New York.

Combs, Bryan. 1995. Successful Teacbing: A Practical Handbook. Heinemann.

Deborah Phillips. Longman Complete Course For The TOEFL, Tests. USA, Longman,Inc.: 2001.

Djamaluddin Darwis. English for Islamic Studies.Jakarta, IAIN walisingo Press: 2003.

Hamidah, Bustami. Digest Islam and Build up Your English. Yogyakarta, Andalas University Press: 2006.

Harmer, Jeremy. How to Teach English: An Introduction to the Practice of English Language Teaching. 1998. England: Addison Wesley Longman.

Harmer, Jeremy. The Practice of English Language Teaching. ---- England: Longman.

Krippendorff . 1981. Content Analysis. An Introduction to Methodology. London:

Leech, Geofrey. 1994. Kamus Lengkap Tata Bahasa Inggris. Jakarta: Kesaint Blanc.

Mendiknas.Undang-undang Guru Dan Dosen.Yogyakarta, Pustaka Pelajar: 2012.

Miles, Matthew B \& Huberman, Michael A. Qualitative Data Analysis.London, Beverly Hills, Sage Publication: 1984. 


\section{1}

Leffi Noviyenty : Upaya Peningkatan Kompetensi Bahasa Inggris.. |

Peraturan Pemerintah RI. Undang-undang Guru dan Dosen. Jakarta, Pustaka pelajar: 2012.

Richards, Jack C and Willy Renandya.Methodology in Language Teaching: An Anthology of Current Practice. 2004. Cambridge: Cambridge University Press.

Savignon, Sandra. 1983. Communicative Competence: Theory and Classroom Practice. Addison - Wesley Publishing.

Sharpe. J. Pamela. 2002. How to Prepare For the TOEFL. Jakarta Pusat: Binarupa Aksara.

Sharpe.J.Pamela. Barron'STOEFL (Test Of English As A Foreing Language), IBT. Indonesia, Binarupa Aksara Publishing: 2012.

Sharpe.J.Pamela. Barron'STOEFL (Test Of English As A Foreing Language), IBT. Indonesia, Binarupa Aksara Publishing: 2012. The University of Chicago Press.

Thornburry, Scoot. How to Teach Vocabulary. 2001. England: Longman.

Yin, Robert. Case Study Research Desing and Methods. London,Sage Publications beverty Hills: 1987. 
172 | BELAJEA : Jurnal Pendidikan Islam, Vol. 3, No. 02, 2018 